\title{
FUNDAMENTOS DO DIREITO INTERNACIONAL: A ESCOLA ITALIANA E O PRINCÍPIO DA NACIONALIDADE DE PASQUALE STANISLAO MANCINI
}

\section{FONDAMENTI DI DIRITTO INTERNAZIONALE: LA SCUOLA ITALIANA E IL PRINCIPIO DELLA NAZIONALITÀ DI PASQUALE STANISLAO MANCINI}

${ }^{1}$ Thayrine Paôla Canteli

\begin{abstract}
RESUMO
O presente trabalho se destina a apresentar o princípio de nacionalidade elaborado pelo jurista italiano Pasquale Stanislao Mancini. A ideia basilar de sua construção teórica, propôs uma grande mudança de paradigmas no séc. XIX no que diz respeito ao estudo do Direito Internacional enquanto ciência autônoma. Partindo de uma breve retrospectiva histórica, o artigo aponta as inspirações teóricas de Mancini, quais sejam Grotius, Vico e Savigny e a contextualização histórico-política em que elaborou sua teoria. Utilizando-se o método dedutivo de abordagem, por intermédio da pesquisa bibliográfica é que, então, foram escolhidos alguns traços centrais da obra manciniana, a serem tratados: (a) elementos constitutivos da Nação; (b) a consciência da nacionalidade; (c) o paradigma estatalista. Definir o conceito de Nação para Mancini significa abordar seus elementos materiais e espirituais e, a partir daí, entender as críticas feitas à sua teoria. Nesse passo, avançando na investigação, o artigo segue na tentativa de apontar os principais traços da construção manciniana que eleva a ideia de nacionalidade como fundamento do Direito Internacional.
\end{abstract}

Palavras-chave: Teoria da nacionalidade, Pasquale stanislao mancini, Consciência da nacionalidade, Escola italiana de direito internacional

\begin{abstract}
Questo lavoro di ricerca ha lo scopo di presentare il principio della nazionalità fatto dal giurista italiano Pasquale Stanislao Mancini. La sua idea principale è una costruzione teorica con la quale propone un grande Cambiamento nello studio del Diritto Internazionale come scienza autonoma nel $19^{\circ}$ seculo. Partendo da una breve retrospettiva storica, larticolo indica le ispirazioni teoriche del Mancini, cio è Grotius, Vico e Savigny e il contesto storico e politico in cui la sua teoria è stata sviluppata. Utilizzando il metodo deduttivo, per mezzo della ricerca bibliografica, ai fini della trattazione sono stati scelti alcuni aspetti centrali del lavoro del Mancini: (a) gli elementi costitutivi della nazione; (b) la coscienza della nazionalità; (c) il paradigma statalista. Definire il concetto di nazione di Mancini significa prendere in considerazione gli elementi materiali e spirituali e, da lì, comprendere le critiche della sua teoria. In questo modo, con il progredire della ricerca, l' articolo prosegue nel tentativo di identificare le caratteristiche principali della costruzione manciniana che eleva l'idea di nazionalità a base del Diritto Internazionale.
\end{abstract}

Keywords: Teoria della nazionalità, Pasquale stanislao mancini, Coscienza della nazionalità, Scuola italiana di diritto Internazionale

\footnotetext{
${ }^{1}$ Mestranda em Direito na Universidade Federal de Santa Catarina - UFSC, Santa Catarina, SC, (Brasil). Assistente de Pós-Graduação na Universidade Federal de Santa Catarina - UFSC, Santa Catarina. (Brasil). -mail: thayrine.canteli@hotmail.com
} 


\section{INTRODUÇÃO}

Tendo como pano de fundo o universo italiano do século XIX, o presente trabalho de pesquisa objetiva problematizar o papel da Teoria da Nacionalidade elaborada pelo jurista italiano Pasquale Stanislao Mancini e compreender sua colaboração para a nascente ciência do Direito Internacional.

Inicialmente se deve destacar que Mancini é considerado um divisor de águas entre o antigo e o novo Direito Internacional, pois foi o grande expoente a transplantar o centro dessa ciência do Estado para a Nação. Com forte aspecto antropológico, esta é sua ideia matriz: construir um princípio da nacionalidade.

A exposição que se segue diz respeito primeiramente às influências teóricas de Grotius, Vico e Savigny que inspiraram Mancini na construção de sua conjectura. Perpassando pelo período do Ressurgimento italiano, estudar-se-á a necessidade de unificação política da península italiana, que foi o gérmen funcional à criação da teoria. Esse desejo de união do povo italiano era reflexo de uma expressão da unidade geográfica, cultural e econômica.

Após esse apanhado histórico de grande relevância, a teoria manciniana das nacionalidades começa a se desenhar. $\mathrm{O}$ autor passa, então, a discorrer sobre os elementos constitutivos de uma Nação, sua ideia matriz.

O fio condutor de seu pensamento se revela na compreensão da nação como uma “identidade cultural”, que possui elementos materiais - geográfico, etnográfico e racional que se ligam a outros como crenças religiosas, costumes, leis e instituições sociais, além da história e das tradições da vida nacional - e um elemento espiritual - consciência de nacionalidade. A reunião desses elementos daria ao princípio da nacionalidade um status de princípio supremo único.

Nesse norte, a consciência da nacionalidade seria um elemento espiritual animador das nacionalidades, nas palavras de Mancini. Este elemento será muito estudado durante este ensaio, principalmente por ser o grande alvo das críticas dos internacionalistas.

Por fim, propondo a aceitação da ideia de nacionalidade como fundamento do Direito Internacional, Mancini visa demonstrar que ela é, sem dúvida, o seu primeiro e mais seguro eixo.

Utilizando-se o método dedutivo de abordagem, por intermédio da pesquisa bibliográfica, o trabalho se mostra de extrema importância para a compreensão do paradigma estatalista do Direito Internacional. 
Nesse sentido, apresenta-se a nação como uma agregação humana com arcabouço cultual e consciência de si mesma, como será demonstrado no decorrer do estudo.

\section{INSPIRAÇÕES TEÓRICAS PARA A TEORIA DAS ACIONALIDADES: DE GROTIUS A SAVIGNY}

Pasquale Stanislao Mancini foi uma personalidade de destaque na vida política italiana do final do século XIX. Muitas vezes é apontado como o fundador da escola italiana de Direito Internacional, bem como seu personagem mais simbólico.

Nuzzo (2012), estudioso italiano que se dedicou ao estudo das teorias mancinianas, o define da seguinte maneira:

[...] o seu perfil biográfico e a sua riquíssima produção - composta de memórias forenses, textos legislativos, discursos parlamentares e projetos editoriais mais do que de obras doutrinárias - dá-nos a verdadeira imagem do jurista italiano do século XIX: advogado, professor, parlamentar. ${ }^{1}$ (NUZZO, 2012, p. 307)

Político, jurista e professor de Direito Internacional, Público, Privado e Marítimo nas Universidades de Nápoles, de Roma e de Turim, Mancini nasceu em Castel Baronia, em 1817, e morreu em Nápoles, em 1888. Foi Ministro da Instrução Pública (1862), da Justiça (1876) e dos Negócios Exteriores $(1881)^{2}$ do Reino da Itália. Além disso, foi deputado do Parlamento.

Diante de sua grandiosa carreira, pode-se afirmar que foi, sobretudo, um homem da política $^{3}$, o que justificará sua eloquência e sua persuasiva habilidade de se expressar.

Desde muito cedo Mancini demonstrava interesse pelo estudo das artes e da sociedade como um todo, conforme reforça Nuzzo (2012, p. 307):

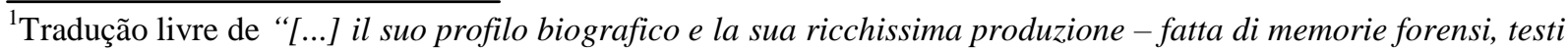
legislativi, discorsi parlamentari, progetti editoriali più che di opere dottrinali - ci restituiscono la vera immagine del giurista italiano del $19^{\circ}$ sec.: avvocato, professore, parlamentare." (NUZZO, 2012, p. 307).

${ }^{2}$ No mesmo ano, o jurista italiano se dedica ao apelo da inevitabilidade de uma renovação no ensino do Direito, como narra Nuzzo (2012, p. 312): "Fiel à ideia de uma vida, em 1881 redige o projeto da Enciclopédia jurídica italiana para corresponder às exigências da radical reforma do ensino, da literatura jurídica nacional e da autonomia das ciências sociais." Tradução livre de "Fedele alle idee di una vita, nel 1881 redige il progetto dell "Enciclopedia giuridica italiana per corrispondere alle esigenze della radicale reforma dell"insegnamento, di una letteratura giuridica nazionale e dell"autonomia delle scienze sociale." (NUZZO, 2012, p. 312).

${ }^{3}$ Nuzzo (2012) nos concede uma explicação acerca do conceito de política, na visão manciniana: "[...] define a política como "ciência e arte", onde ciência está para a ciência do governo, como parte do direito público, e arte consiste no estudo e na aplicação da lei da oportunidade [...] que indica o caminho da civilização humana e do incremento dos estados segundo o Direito". Tradução livre de "definisce la politica "scienza e arte", dove scienza sta per scienza dal governo, quale parte del diritto pubblico, e arte consiste nello studio $e$ nell"applicazione della legge dell"opportunità [...] che indica la via dell"umano incivilimento e dell"incremento degli Stati secondo il Diritto." (NUZZO, 2012, p. 309)
} 
Com atividade incansável e considerável versatilidade, Mancini demonstra desde muito jovem interesse pelo aprofundamento de disciplinas diferentes da jurídica. Além da paixão pela literatura, poesia, música, leitura da Bíblia (...) se ocupa com questões sociais com escritos sobre a educação, sobre colônias agrícolas, sobre prisões e o sistema penitenciário. ${ }^{4}$

Nuzzo (2012, p. 309) ainda afirma que "[...] sua longa carreira política liberal constantemente conotada da aspiração a mediar entre princípios gerais e contexto histórico e nacional, entre ciência, politica e opinião pública - iniciou em 1848." ${ }^{, 5}$ Esse ano realmente marcou a vida do jurista italiano, pois foi o ano em que aderiu ao movimento constitucional em Nápoles e foi forçado a abandonar a sua terra natal para desembarcar como exilado em Turim, capital do Reino de Sardenha.

Foi assim que, "envolvido em acusações de rebeliões (desde a sentença em 1853 de vinte e cinco anos de prisão), em 27 de setembro de 1849 foge em exilio e se estabelece em Turim onde é estimado. [...] Rapidamente habilitado ao exercício da advocacia, prossegue os estudos com projetos de publicações." (NUZZO, 2012, p. 310)

Em novembro de 1850 foi chamado para lecionar a cátedra de Direito Público Internacional instituída a pouco tempo no curso de Direito da Universidade de Turim. Nuzzo (2012, p. 310) afirma com fascínio que "[...] a teoria produziria um efeito de ameaça de uma revolução na ciência." ${ }^{, 7}$ Faz referência a importantíssima contribuição de Mancini à ciência do Direito Internacional, realizada principalmente em seus discursos na Universidade supracitada.

Preliminarmente cumpre observar que a fala de Mancini representa a marca forte do romantismo italiano, com o uso da retórica. Com uma vigorosa propensão de escrever poesia enquanto faz doutrina, Mancini “[...] demonstra ainda sofrer o influxo de elementos da cultura jurídica que a partir da primeira metade do século XIX é construída sobre o paradigma oratório-forense.” (DAL RI, 2014, p. 254)

Ademais Mancini é constantemente considerado um divisor de águas entre o antigo e o novo, como assegura Nuzzo (2007, p. 164): “De nação ao estado, do direito das gentes à

\footnotetext{
${ }^{4}$ Tradução livre de "Con attività instancabile e considerevole versatività, M. dimostra fin da giovanissima età interesse per l"approfondimento di discipline differenti da quella giuridica. Oltre che la passione per la letteratura, la poesia, la musica, la lettura della Bibbia [...] si impegna nelle questioni „sociali" con scriti sull "istruzione, sulle colonie agricole, le carceri, e il sistema penitenziario" (NUZZO, 2012, p. 307)

${ }^{5}$ Tradução livre de "La sua lunga carriera politica "liberale" - constantemente connotata dall"aspirazione a mediare tra principi generali e contesto storico e "nazionale", tra scienza, politica e opinione pubblica - inizia nel 1848." (NUZZO, 2012, p. 309)

${ }^{6}$ Tradução livre de "Coinvolto nelle accuse di ribellione (fino alla condanna nel 1853 a venticinque anni di galera) il 27 settembre 1849 fugge in esilio e si stabilisce a Torino dove è stimato [...]. Subito abilitato all"esercizio dell"avvocatura, prossegue gli studi con progetti di pubblicazioni." (NUZZO, 2012, p. 310)

${ }^{7}$ Tradução livre de "[...] la teoria avrebbe prodotto l"effetto di minaccia di uma rivoluzione nella scienza". (NUZZO, 2012, p. 310)
} 
ciência do direito internacional o salto, contudo, não é simples nem automático. Exige filtros. Pasquale Stanislao Mancini constitui um dos mais importantes desses filtros."8

Foi dessa forma que o Princípio de Nacionalidade, pedra angular do discurso de Mancini - e, de muitos expoentes da escola italiana - foi levado adiante como o cerne do Direito Internacional.

O discurso manciniano acerca do Princípio da Nacionalidade ${ }^{9}$ se deve também, mas não somente, ao seu funcionalismo à unificação política da Itália, como será visto posteriormente, além de instigar a formação de um Direito internacional renovado que vai se desenhando e tomando novas formas com as elaborações teóricas.

Nesse quadro se coloca Mancini como um grande expoente a transplantar o centro do Direito Internacional do Estado para a Nação. De acordo com o ensinamento de Messineo (2013, p. 890), “[...] no princípio, a teoria das nacionalidades estava sendo muito bem sucedida por causa da repercussão com o projeto da unificação nacional. Era apenas natural [...] que a mesma poderia desaparecer assim que o estado Italiano adquirisse autonomia." 10

O próprio autor, quando faz um explanação acerca da origem do Direito Internacional nas sociedades grega, romana até chegar ao século anterior ao seu, deixa evidente que ainda não se tinha concretizado uma ciência. Segundo ele "[...] o astro da ciência não se mostrava ainda no horizonte e, segundo opinião comum, é preciso esperar até o século XVII para saudá-lo no holandês Grotius.” (MANCINI, 2003, p. 24).

\footnotetext{
${ }^{8}$ Tradução livre de "Dalla nazione allo stato, dal diritto delle genti alla scienza del diritto Internazionale il salto tuttavia non è simplice né automatico. Richiede dei filtri. Pasquale Stanislao Mancini costituisce uno dei piú importante di questi filtri." (NUZZO, 2007, p. 164 )

${ }^{9}$ A título propedêutico, optou-se por expressar aqui trecho em que Mancini revela que: “[...] algumas propriedades e fatos constantes que, superando os limites das regiões e dos séculos, deveriam ser encontradas ainda agora junto a alguma das tantas nações que até aqui viveram. A região, a raça, a língua, os costumes, a história, as leis, as religiões são, entre esse grande número, as principais." (MANCINI, 2003, p. 33). Vale destacar, ainda, que a teoria não foi uma inovação, conforme aponta Messineo (2013, p. 888): "[...] teorias italianas eram muito bem conhecidas nos meios europeus. Pasquale Stanislao Mancini (1817-1888) foi o primeiro presidente do Instituto e um político notável do novo Reino da Itália, onde ele foi Ministro Estrangeiro entre 1881 e 1885 . Sua teoria de nacionalidades, formulada primeiramente nos meados de 1850 , o deram uma dimensão legal internacional para o projeto político de Giuseppe Mazzini sobre a libertação Italiana das dominações estrangeiras." Tradução livre de "[...] Italian theories were very well known in European circles. Pasquale Stanislao Mancini (1817-1888) was the first president of the Institut and a prominent politician of the new Kingdom of Italy, of which he was the Foreign Minister between 1881 and 1885. His theory of nationalities, which he first formulated in the 1850s, gave an international legal dimension to Giuseppe Mazzini's political project of Italian liberation from foreign domination." (MESSINEO, 2013, p. 888)

${ }^{10}$ Tradução livre de "At the outset, the theory of nationalities had been very successful because of its resonance with the project of national unification. It was only natural (...) that it would all but disappear once the Italian state came of age." (MESSINEO, 2013, p. 890)
}

Pode-se extrair dessa afirmação uma de suas inspirações teóricas mais expressivas.

Grotius (1583-1645) foi um dos primeiros estudiosos a falar do Direito Internacional como 
ciência $^{11}$. Isso ocorre porque, como um dos fundadores da Escola do Direito Natural, trouxe uma grande inovação para a época, qual seja afirmar que o fundamento para o direito natural prescinde de Deus $^{12}$ e que a teologia, o direito e a política são coisas autônomas ${ }^{13}$.

O ponto central de sua discussão, solidificado no "De Jure Belli ac Pacis", foi mostrar os principais contornos do jus gentium, evidenciar uma sociedade internacional com a dessacralização da guerra, sempre buscando instrumentos para manter a paz, bem como interrogar se haveria guerra justa e que tipo de guerra seria justa.

Ainda nos prolegômenos, Grotius demonstra a existência de uma "lei superior" e refere-se a ela como "perpétua". Para ele, as leis civis valem apenas para os tempos de paz, mas existem outras leis que não se calam diante das armas pois são válidas tanto para os tempos de paz como para aqueles de guerra. Villey (2009, p. 641) explica que essa lei superior se refere a uma lei da natureza e nos remete ao conceito de jus gentium como sendo "uma lei comum [...] independentemente das opiniões e costumes particulares e que se impõe igualmente a todos, para além das fronteiras; pois existe entre todos os homens um parentesco natural".

Pode-se ver nesses contornos a inspiração de Mancini para uma teoria que via a Nação, o Povo como unidade orgânica, ponto que será articulado adiante.

Não custa relembrar que o homem, para Grotius, é um animal de natureza superior que tem a necessidade da sociabilidade, e nisso se encontra o fundamento do direito. Além desse diferencial, o homem possui dois instrumentos importantes: a razão e a linguagem.

Macedo alerta para o significado do jus gentium de Grotius, no qual gentes significa "povos". Assim, "O direito das gentes refere-se àquela lei comum entre os povos, que se

\footnotetext{
${ }^{11}$ Mancini cita outros autores do passado para afirmar que "[...] Não há dúvida que a grande obra de Grotius obscureceu e se sobrepôs a todas as precedentes. É difícil encontrar outra que, ao aparecer, tenha conseguido maior fama, obtido a honra de mais numerosos e diversificados comentários e exercitado uma influência mais sensível sobre a política dos governos da cristandade para amenizar suas relações recíprocas em proveito da civilização e da justiça.” (MANCINI, 2003, p. 26)

${ }^{12}$ Grotius se situa entre as tradições jus naturalistas medieval e moderna. Isso vai definir a sua matriz teórica, além de representar os tempos de transição da era medieval com característica teocêntrica para um mundo moderno em busca da laicização. Por essas razões Macedo (2006, p. 1) afirma que "sua vida e seus escritos [...] encerram o antigo e o novo". Vale lembrar que Grotius não pregava o ateísmo, mas se destacava por separar direito e teologia. Quanto à utilização da história na obra analisada, Macedo (2006, p. 41) destaca que "[...] em nada lembra o esforço de investigação de um historiador contemporâneo; significa, antes, a referência a eventos da antiguidade, quanto mais antigos, maior a autoridade dos exemplos. E trata-se também de uma referência indireta, sempre mediada pela bíblia ou pelos escritores clássicos".

${ }^{13}$ Segundo Macedo (2006, p. 2), Grotius "foi um homem bastante versátil. Conseguiu ser, no tempo de uma vida, poeta, teólogo, historiador, filósofo, filólogo, pensionário de Roterdã, diplomata e, em momentos tão gloriosos, prisioneiro político e exilado. Mas, acima de tudo, foi um jurista." Complementando essa informação, Macedo (2006, p. 10) afirma que "na prática, Grócio precisou estudar um pouco de todas as ciências da época". Provavelmente esse inegável intelecto fascinou Mancini, que também era um homem muito culto e interessado em literatura e nas artes em geral, como exposto acima.
} 
reflete nos costumes e nos tratados.” (MACEDO, 2006, p. 68). Portanto, as fontes do Direito Internacional (que é um direito positivo) seriam o consenso dos povos e o próprio direito natural.

Muitos desses elementos também se encontram na teoria manciniana sobre a nacionalidade o que denota mais um estímulo teórico retirado daquele autor.

Não se pode deixar de adentrar ao conceito de Direito ${ }^{14}$, onde restam claras as características essenciais da sociedade para Grotius: ela deve ser organizada e pacífica. Além disso, o Estado seria apenas uma associação de indivíduos que voluntariamente se unem pelo elemento vontade ${ }^{15}$. O Estado é uma comunidade de leis e de soberania e o soberano deve observar o Direito Natural, o direito das gentes o direito civil pois ele não possui poderes ilimitados. Mancini também se apropria e remodela esse conceito de Estado, como será visto mais adiante.

Os ensinamentos de Vico (1668-1744), da mesma forma, representaram forte influência na elaboração manciniana, principalmente no que diz respeito aos elementos caracterizadores de "Nação". Segundo Mancini, a única tentativa considerável de reforma do direito dos povos foi edificada por Vico, na Itália. Devido a isso explicita:

[...] não receio cometer um ato de vaidade nacional, afirmando que somente na Itália na mesma primeira metade do século passado um intelecto milagroso que apresentou ao mundo o novo fenômeno de romper a cadeia progressiva que compõe a história das ciências, só ele percebeu um grande e fecundíssimo conceito que por uma direção diferente poderia restaurar de modo estupendo a doutrina jurídica das relações internacionais. Acredito ter apontado Giambattista Vico, sem necessidade de citá-lo. (MANCINI, 2003, p. 28)

Vico, não era internacionalista ${ }^{16}$, mas um filósofo historicista italiano que se dedicou ao estudo do "mundo das nações", como denominado por ele em Principi di una scienza

\footnotetext{
${ }^{14}$ No discurso mancinianao o Direito aparece como produto das leis da natureza, sendo Deus o legislador, como se evidencia a seguir: "Desse modo, enquanto os outros até agora puseram as bases supremas da ciência em fatos e leis que brotaram e foram produzidas pela vontade humana e, como ela, mutáveis e variadas, nós, pelo contrário, essas mesmas leis, esses acordos e esses costumes, submetemos à autoridade de leis mais sublimes e veneráveis, das quais é eloquente e não mentirosa reveladora no mundo dos povos a natureza, sendo legislador, Deus." (MANCINI, 2003, p. 63)

${ }^{15}$ Macedo (2006, p. 80) afirma que "[...] essa visão de uma sociedade internacional, composta de pessoas e não de Estados, deve-se também ao fato de que o autor não possui um conceito bem preciso de Estado". Ainda em Macedo (2006, p. 86), se encontra o seguinte trecho: "O Estado em Grócio, não possui os contornos bem delineados. Pode-se encontrar argumentos a favor tanto do absolutismo como da liberdade.".

${ }^{16}$ Per assecondare un desiderio del padre che lo voleva giurista, frequentò per un paio di mesi le lezioni private (...) e si iscrisse per tre anni, dal 1688 al 1691, ma senza seguirne i corsi, alla facoltà di giurisprudenza dell'università di Napoli. Prese a studiare il De iure belli et pacis di U. Grozio, e tanto ne fu preso, che Grozio fu da allora da lui considerato come il quarto dei suoi "autori". Ciò posto, Dio solo conosce le cose della natura perché ne è il creatore; l'uomo non può attingere siffatta conoscenza, ma semplicemente potrà conoscere gli aspetti esteriori delle cose, non la natura o causa che ne costituisce l'intima struttura; potrà invece pienamente conoscere le matematiche perché qui l'uomo è il creatore del "mondo di figure e numeri" di cui esse sono
} 
nuova dintorno alla natura delle nazioni, como objeto da nova ciência que unia filologia e filosofia, que indicaria as ideias e as leis eternas que governam a história. Apesar de seu enfoque filosófico, Vico foi considerado por Mancini como o primeiro doutrinador que procurou encontrar um fundamento jurídico da nacionalidade.

Sobremais, Mancini se fundamentou na teoria de Vico para afirmar de forma categórica que as Nações formam as unidades básicas da organização humana. Por sua vez, a humanidade das nações representaria o real progresso civil visando o fim supremo do Direito Internacional: desenvolvimento das nacionalidades. Por fim cabe destacar que "Na distinção entre jurista e advogado, a filosofia e a história são entendidas por ele no sentido de Vico como instrumentos imprescindíveis para a formação: estéril é a simples explicação das leis positivas do seu próprio país." ${ }^{17}$ (NUZZO, 2012, p. 307-308)

Savigny (1779-1861) que já havia tentado delinear o conceito de Nação na ciência jurídica, com certo êxito, foi outro personagem que influenciou a teoria manciniana. Segundo Dal Ri (2014, p. 255), as concepções de Nação de Mancini e Savigny são aproximadas, “[...] mesmo que as análises dos dois juristas apresentem diferenças, enquanto, principalmente para o segundo, análise do conceito ocorre como funcional a sua luta contra a codificação do direito privado." ${ }^{18}$. De outro norte, Mancini entra nas nuances do conceito de Nação para fixar sua teoria central e afirmar que somente a Nação é sujeito de Direito Internacional.

Em sua quarta preleção, ocorrida em Torino em 1858, intitulada "Progressos do direito na sociedade, na legislação e na ciência durante o último século em relação com os

costituite. Questa è l'ispirazione centrale della Scienza nuova: una scienza della storia è possibile perché il mondo della storia è fatto dagli uomini, per cui se ne possono ritrovare i principî e le leggi "entro le modificazioni della nostra medesima mente umana". in stretto rapporto con la verifica, che potremmo dire "sperimentale", data dalle ricerche della filologia. As informações reportadas foram extraídas de: www.treccani.it/enciclopedia/giambattista-vico/. Acesso em: 29 de julho 2015.

${ }^{17}$ Tradução livre de "Nella distinzione tra giurista e avvocato, la filosofia e la storia sono da lui vichianamente intese come strumenti imprescindibili per la formazione: sterile è la mera spiegazione delle leggi positive del proprio paese." (NUZZO, 2012, p. 307-308)

${ }^{18}$ Sobre o debate acerca da necessidade da codificação do Direito Civil Alemão em 1814, basta destacar que foi uma grande disputa teórica entre Thibaut com a tese exposta na obra Über die Notwendigkeit eines allgemeinen bürgerlichen Gesetzbuch für Deutschland ("Sobre a necessidade de um Código Civil geral para a Alemanha") e Savigny, baseado na Von Beruf unserer Zeit für Gesetzgebung und Rechtswissenschaft ("Sobre a vocação do nosso tempo para a legislação e a ciência do direito"). Por um lado Thibaut, com forte inspiração racionalista, queria garantir a unidade e a sistematização do direito alemão em um único corpo legislativo, uma vez que, devido a sua fragmentação, vivia um sistema repleto de inseguranças jurídicas. Por sua vez, Savigny contesta as ideias apresentadas com claro viés conservador, afirmando que os costumes do povo seriam a fonte primária do direito, e não lei. Naquele momento, a posição adotada por Savigny foi assumida pela Alemanha, tendo em vista que a codificação do direito civil alemão somente teve lugar no início do século XX. Por suas ideias inovadoras, Savigny pode ser considerado um divisor de águas. Ele inaugura uma nova ciência jurídica, onde o direito vai se delineando e se separando dos conhecimentos filosóficos, históricos, etc. 
princípios e com as ordens livres"19 , Mancini (2003, p. 112) faz um apanhado histórico de um século e pondera sobre a época das $\operatorname{codificações~}^{20}$, como um lento e gradual progresso legislativo, político e econômico, como explicitado a seguir

\begin{abstract}
Assim aconteceu nesse período, apesar dos perigosos ensinamentos e os conselhos de inércia da escola histórica, que surgiu na Alemanha, em combater a obra da codificação e em representar o Direito e suas reformas como efeito espontâneo e sucessivo dos costumes e do gênio de cada nação, não diferente das línguas, sem necessidade do concurso de reformadores, filósofos ou juristas, a Europa viu em todas as suas regiões serem promulgados novos códigos, mais ou menos feliz transição e aliança entre o elemento histórico e o filosófico, entre as tradições do passado e as verdades racionais e eternas reveladas nas necessidades da natureza humana.
\end{abstract}

De Savigny extrai principalmente o pensamento de que o Direito vive na consciência do povo, destacando o caráter vivo do direito.

Esse Direito estaria sempre em mutação, assim como as demais tendências de um povo e seria, portanto, resultado da experiência espontânea. Assim, essa ideia de movimento reflete o direito de um povo como produto orgânico de sua história e não como criação indiferente do legislador.

Em suma, Mancini retira as seguintes convicções da teoria de Savigny: (a) A consciência nacional como fonte primeira do Direito (Volksgeist) ao lado do costume legislado e da ciência; (b) o Direito como fato histórico, inerente a um grupo humano; (c) o povo como sujeito ativo do direito, como algo trangeracional; (d) o caráter cultural do Direito como produto da construção histórica dos povos; e (e) evolução continua e lenta do Direito, desprezando a ideia de rupturas.

\footnotetext{
${ }^{19}$ Nessa parte da obra visa se debruçar sobre os progressos do Direito na sociedade, na legislação e na ciência de um século para cá. Seu marco temporal são os últimos cem anos e seu objetivo é tratar da historia jurídica da Europa. O autor afirma que os últimos cem anos foram uma das épocas "mais clássicas e fecundas da história do Direito e talvez superior a quantas outras a precederam, por insólito e prodigioso poder de ideias e de forças postas em ação, por grandeza de acontecimentos e pela prática influência exercida sobre a condição dos homens e das nações.” (MANCINI, 2003, p. 100)

${ }^{20}$ Ainda sobre o período das codificações, o jurista italiano externa suas considerações "[...] eram duas forças que haviam conspirado em operar um só e mesmo efeito, isto é, aquele de dividir o Estado em inumeráveis restritas frações territoriais" [...] "Dessa maneira, cada Estado continha centenas de legislações locais, diferentes entre si, umas ao lado das outras, todas em vigor e observância" [...] "A necessidade de ordem e de unidade legislativa, o desejo de novos códigos, universalmente sentido, não era satisfeito em parte alguma." (MANCINI, 2003, p. 107)
}

É preciso insistir que o "espírito do povo" de Savigny marca os traços culturais comuns dos membros de um mesmo povo. Esse componente comum é repassado entre as gerações pela tradição e influencia as consciências individuais. Da mesma forma, Mancini adere ao pensamento de Savigny para elaborar sua tese de consciência da nacionalidade, que 
será objeto de análise em linhas ulteriores.

Em seu discurso Mancini sustenta que é dever dos italianos procurar os verdadeiros princípios da ciência, seguindo sempre os passos dos grandes mestres, cujas obras até então eram infecundas e negligenciadas.

\title{
2. A ITÁLIA DO SÉCULO XIX: CONTEXTO HISTÓRICO DO DESENVOLVIMENTO DO DISCURSO DE MANCINI
}

Para uma correta compreensão da teoria das nacionalidades apresentada por Mancini, se faz necessário, em caráter propedêutico, entender o momento histórico que vivia a sociedade europeia do século XIX.

O século XIX, cujo posicionamento jurídico é extremamente formalista, se distancia aos poucos de concepções jusnaturalistas. Juntamente com a gradativa preocupação com a secularização do direito, a adoção do modelo positivista visava colocar o homem racional como sustentáculo do direito, em detrimento da natureza. O positivismo, enquanto ciência indicava que o conhecimento científico se concretizava por meio da observação empírica, ou seja, de experiência dos fatos. Nuzzo (2012, p. 308-309) destaca que

\begin{abstract}
O direito público, em particular, constitui a ordem política que, no que diz respeito aos "limites invariáveis" possui a tarefa de tutelar todas as "personalidades" e de valorar quando necessário uma intervenção "nas coisas religiosas, na educação moral e científica dos cidadãos, nas artes, na indústria, no comercio". Mancini também afirma que as leis positivas devem ser especificações dos princípios do direito natural no que diz respeito às especiais e variáveis condições de cada povo. ${ }^{21}$
\end{abstract}

A doutrina contratualista, muito presente nesse período, é rejeitada por Mancini, pois, para ele, a ideia de estado de sociedade posterior ao estado natural, não passava de algo abstrato e arcaico que deveria ser substituído pela Nação, algo mais fiel à realidade italiana daquele tempo. Na sua obra "Diritto Internazionale", trata rapidamente do contratualismo, mas se afasta de suas ideias matrizes elaborando a seguinte crítica:

\footnotetext{
${ }^{21}$ Tradução livre de "Il diritto pubblico, in particolare, costituisce l"ordine politico che, nel rispetto dei "limiti invariabili", ha il compito di tutelare tutte le "personalità" e di valutare quando si renda necessário um intervento "nelle cose religiose, nella educazione morale e scientifica de" cittadini, nelle arti, nella indústria, nel commercio". M. sostiene inoltre che le leggi positive devono essere specificazioni dei principii del diritti naturale rispetto alle speciali e variabili condizioni di ciascun popoli. (NUZZO, 2012, p. 308-309)
}

Nem de maneira diversa pensavam os liberais do século XVIII, cujo evangelho era o contrato social. Uns e outros convergiam nisso e, aos olhos deles, não as Nações, mas seus governos eram os sujeitos capazes do liame jurídico e, portanto, o direito dos povos se tornava a lei natural dos Estados e não dos povos. (MANCINI, 2003, p.42) 
Em análise última, pode-se considerar que Mancini foi um historicista antropológico ou cultural (não social) que trouxe elementos de um jusnaturalismo laico e se afastou completamente do contratualismo.

Vale lembrar que envolve uma conjuntura marcada por movimentos revolucionários e patrióticos aquela em que se desenvolve a teoria manciniana, que mais tarde se revela em um momento jurídico.

De modo geral, o séc. XIX foi palco de inúmeros movimentos revolucionários, agitações e ásperas lutas. A Itália, mesmo sendo geograficamente uma península compacta, era retalhada em inúmeros Estados subjugados e dominados há séculos pela França, Áustria e Espanha.

Considerada um verdadeiro mosaico de Estados, a Itália se encontrava em um período de grandes mudanças almejando uma verdadeira restauração da unidade nacional. É evidente que as lutas políticas e os movimentos de libertação nacional para conquistar a tão aspirada independência foram acompanhados pela elaboração jurídica de intelectuais que desenvolveram contribuições doutrinárias voltadas à formação de uma consciência nacional.

Aqui se encaixa a grande contribuição feita por Mancini: justificar com fortes argumentos a importância de se considerar a Nação como sujeito do Direito Internacional. Os elementos e as peculiaridades do conceitos de Nação, que são objeto do presente estudo, são delineados e elevam a importância da raça, da língua, do território, da história, das religiões, etc, quebrando o ciclo de doutrinas que consideravam o Estado como ente representativo das diversas culturas.

É preciso insistir no fato de que a Itália era fragmentada em diversos Estados sob o domínio estrangeiro. A consciência dessa baliza histórica cientifica a maestria da Teoria das nacionalidades, que

[...] representou o húmus intelectual do Risorgimento italiano. Nela se atrelaram, até se sobreporem, o pensamento político que guiou a ação revolucionária para conquista da unidade e da independência da Itália e a reflexão jurídica que antecedeu e sucessivamente sustentou a edificação do novo Estado nacional. ${ }^{22}$ (TREGGIARI, 1991, p. 275).

A proposta manciniana pode ser considerada um projeto político de unificação da Itália. Afinal, o país possuía uma unidade histórica, uma realidade material e espiritualmente única, fatores que traziam ao povo uma ânsia pela unidade política. 
Essa realidade também era compartilhada por vários países europeus da época. Em razão disso, frisa-se que essa doutrina não foi pensada para ser aplicada exclusivamente no território italiano. De fato:

[...] ela devia ser aplicável não apenas na Itália, mas também em todos os países da Europa, de forma que a luta pela independência italiana se tornaria o símbolo do prelúdio de um movimento mais vasto que apelava a todos os homens livres em toda a Europa. Foi para satisfazer tais necessidades que nasceu a "doutrina das nacionalidades" italiana. ${ }^{23}$ (SERENI, 1943, p. 155-156)

O período do Risorgimento, momento precedente à unificação da Itália (que ocorre apenas em 1861), é entendido como o gérmen intelectual da escola italiana de Direito Internacional.

É de se atentar que a consciência de Nação foi se desdobrando e se estendendo durante muito tempo ${ }^{24}$, mas foi apenas no Ressurgimento que se tornou algo tangível. Logo, em vista disso, a noção do Princípio da Nacionalidade foi produto de uma complexa evolução temporal que encontrou suas melhores formas no contexto italiano apresentado.

O Romantismo influenciou várias áreas do conhecimento como a filosofia, a literatura e as artes, destacando-se os indivíduos e seus sentimentos e procurando desvendar as particularidades nacionais, como aponta Biazi (2014, p. 33-34)

\begin{abstract}
A nação como entidade de origem cultural, social, étnica e analisada sob vários perfis, começou a constituir objeto de indagação por parte dos juristas entre os séculos XVIII e XIX. O Romantismo - e consequentemente o Risorgimento - que possuía várias vertentes - literária, filosófica, política - começava então a considerar a nação do ponto de vista jurídico e os juristas que iriam se ocupar dessa temática foram, principalmente, internacionalistas. O mito cultural cedeu o lugar ao mito político.
\end{abstract}

\footnotetext{
22 Tradução livre de: "La dottrina della nazionalità ha rappresentato l"humus intellettuale del Risorgimento italiano. In essa si sono congiunti, sino a sovrapporsi, il pensiero politico che ha guidato l"azione rivoluzionaria per la conquista dell"unità e dell"indipendenze dell"Italia e la riflessione giuridica che ha preceduto e poi sorretto l"edificazione del nuovo Stato nazionale”.(TREGGIARI, 1991, p. 275).
} 
Pode-se dizer sem dúvida que o panorama do Ressurgimento propiciou as condições para a introdução do conceito de nação no universo jurídico, onde a teoria elaborada por Mancini representou de forma notável a máxima expressão dos ideais românticos.

A retrospectiva que se fez permite compreender a visão histórica sobre o qual o autor se debruça, além de permitir ao estudioso da história do direito internacional assimilar o contexto vivido pelo próprio autor. Apontadas essas noções preliminares, tem-se o ponto de partida para a Teoria da Nacionalidade, motivadora do presente estudo.

\section{TRAÇOS DO PENSAMENTO DE MANCINI ACERCA DO CONCEITO DE NACIONALIDADE}

A concepção de Mancini acerca das nacionalidades é, sem dúvida, sua teoria central. Vale ressaltar novamente a figura eloquente de jurista que Mancini representa ${ }^{25}$, e que caracterizava o ensino do Direito naquele período, onde "[...] a palavra falada assume o centro das atividades do jurista, em detrimento daquela escrita que no final do século XX irá caracterizar o "jurista-cientista” do tecnicismo." (DAL RI, 2014, p. 255)

Essas características pessoais acabam por justificar o fato de grande parte da obra do internacionalista italiano derivar de conferências e discursos. Com tal característica se desenvolve a obra fundamental na qual se baseia esse breve estudo, cujo título original é "Diritto Internazionale”.

\footnotetext{
${ }^{23}$ Tradução livre de: "It had to be applicable not only in Italy but also in all the countries of Europe, so that the struggle for Italian independence would become the symbol of and the prelude to a vaster movement appealing to all free men throughout Europe. It was to satisfy these needs that was born the Italian "doctrine of nationalities. "(SERENI, 1943, p. 155-156)

${ }^{24}$ Para um aprofundamento do estudo da história do conceito de nação ver CHABOD, Federico. L"idea di nazione. Bari: Edizioni Laterza, 1967.
} 
Os escritos foram publicados em 1873 e apresentavam sua concepção sobre a nacionalidade, elaborada no período anterior à unificação politica da Itália, sendo sua obra mais conhecida e que o conferiu um grande renome. A obra é um conjunto de "prelezione"26, ocorridas entre os anos de 1851 a 1872, reunidas e organizadas para condensar suas ideias centrais acerca da crescente ciência do direito internacional e do ensino jurídico italiano.

Mancini se volta constantemente à juventude italiana estudiosa do Direito ${ }^{27}$ para acentuar a necessidade de mudança de paradigmas. Reforça seu objetivo no seguinte trecho “[...] fazer sentir vivamente a necessidade de uma grande reforma, para a qual possa surgir algum intelecto forte que a tente.” (MANCINI, 2003, p. 55). E, ainda:

\begin{abstract}
Quero confiar a ti, valente juventude subalpina, aquilo que provo ao ver-te aqui reunida em torno de mim pela primeira vez. Uma secreta emoção agita minhas fibras porque voltam a minha memória teus pobres irmãos de outra região da Itália que, durante o decurso não breve de anos, me acostumei a ver aglomerar-se com afeto a meu lado para o estudo das doutrinas jurídicas. (MANCINI, 2003, p. 55)
\end{abstract}

Conscientes do escopo almejado pelo autor, resta expor que suas preleções foram realizadas para inaugurar os períodos letivos e que seu discurso é voltado aos acadêmicos de Direito da época.

Adentrando nas especificidades da obra, pode-se mencionar que sua primeira preleção intitulada "A nacionalidade como fundamento do Direito dos Povos", ocorrida em Turim, em 1851, sintetiza sua ideia matriz que conduzirá o restante de suas concepções. Sem dúvida é o capítulo mais importante, pois expõe sua teoria central: a Teoria das Nacionalidades.

\footnotetext{
${ }^{25}$ Além disso, sua paixão pela docência e pela sapiência do Direito Internacional fica evidente quando da leitura da obra, que muitas vezes chega a comover o leitor. Um exemplo de sua eloquência se encontra no seguinte trecho: "Como se a terra fosse um teatro estreito para as grandes obras do gênio italiano, este, em épocas ainda tenebrosas e miseráveis, rompeu-lhe impaciente os claustros e se lançou orgulhoso e confiante na imensidão do oceano". (MANCINI, 2003, p. 83). Como se nota o autor se refere ao fato de que a ciência e a legislação são criação do pensamento italiano.

${ }^{26}$ Significa o discurso que introduz um curso ou um ano acadêmico. In: Treccani. L"enciclopedia italiana. Disponível em: http://www.treccani.it/vocabolario/prelezione/. Acesso em 20 de agosto de 2015. Sobre a retórica dos juristas, sob forma de preleções, ver a contribuição de Giovanni Cazzetta. CAZZETTA, Giovanni. Prolusioni, prelezioni, discorsi. L"identità nazionale nella retórica dei giuristi. In: CAZZETTA, Giovanni (org.). Retoriche dei giuristi e costruzione dell"identità nazionale. Bologna: il Mulino, 2013, p.11.

${ }^{27}$ No final da primeira preleção, percebe-se certa singeleza e despretensão do autor, ao expor que seu intento é unicamente preparar a juventude para a instauração da ciência do Direito Internacional. Isso se evidencia na sua otimista fala seguinte: "Filhos primogênitos da Itália para a vida da liberdade e para os estudos de sabedoria civil, esperanças prometedoras do suspirado futuro da península, sabereis cumprir os graves deveres que a Providência vos impõe." (MANCINI, 2003, p. 56). Também no início da quarta preleção, inicia seu discurso "coroando essa juventude" "e como que a lhe relembrar com sua presença o que dela espera a Pátria". Essa é uma característica do autor que chama muito a atenção. Ele sempre se dirige à juventude italiana com muita esperança e empolgação. A leitura é muito envolvente transmite muita paixão pela docência e pela Itália.
} 
O autor inaugura a conferência discorrendo sobre a importância e a necessidade de se instituir uma cátedra de Direito Internacional na Itália. Com o intuito de justificar a relevância de se considerar o Direito Internacional como uma ciência autônoma ${ }^{28}$, desvinculada de outras, atesta: “[...] a ciência à qual é legado propugnar o dogma da Independência das Nações, antes que ver-se no entanto confundida com outras no ensino, como se fosse disciplina secundária, bem merecia mais extenso e distinto domínio.” (MANCINI, 2003, p. 20).

Em assonância com a lição de Mancini, o progresso incessante da humanidade deve perpassar pelo desenvolvimento e reforma das ciências, no caso de seu campo de estudo, esse aperfeiçoamento era ainda mais necessário devido ao abandono frente às necessidades daquele tempo. Sua preocupação com o ensino do Direito é notório e salta aos olhos do leitor em diversas passagens. Em verdade:

\begin{abstract}
O ensino deve visar às necessidades do século e as tendências da atual geração, se quiser ser algo mais que um catecismo de áridas abstrações, de minúcias escolares, de fórmulas vazias, sem vida e sem aplicação prática que deixem os ouvintes frios e impassíveis e não acendam em suas mentes aquele calor de virtuoso afeto que somente os germes das doutrinas podem fecundar. (MANCINI, 2003, p. 22)
\end{abstract}

Tendo em mente a necessidade de reforma no ensino e no estudo do Direito Internacional, Mancini explicita que o Direito não é produto da vontade humana, mas “[...] é sempre uma necessidade da natureza moral, a força aplicada de um princípio da ordem moral que procede de uma região superior daquela em que os homens vivem e querem." (MANCINI, 2003, p. 32). No trecho seguinte o autor revela sua teoria fundamental: [...] "reconhecer na coexistência das Nacionalidades, segundo a lei do Direito, o fato principal de nossa ciência, sua primeira verdade" (MANCINI, 2003, p. 32)

Seus escritos propõem a elaboração de um novo ius gentium a partir do princípio de nacionalidade como alicerce sólido desse novo edifício: o direito internacional como ciência $^{29}$. De fato, Mancini foi um dos primeiros homens que montam uma ciência do Direito Internacional.

\footnotetext{
${ }^{28}$ Nesse passo Mancini apela aos intelectuais italianos, nos seguintes dizeres: "Os tempos exigem, porém, que os intelectuais que se propõem a cultivar a disciplina do direito internacional se empenhem em vingar essa ideia de vil desprezo e a elevem à dignidade de uma solene e reconhecida verdade científica, de um conceito filosófico, de uma pregação incontrastável da razão, de uma evidência obtida em virtude de rigorosas demonstrações, de tal modo que dela germinem fortes e tenazes convicções em todas as consciências." (MANCINI, 2003, p. 21)
} 
Sua obra, considerada a primeira contribuição sistematizada sobre o princípio das nacionalidades, elenca os elementos constitutivos da Nação, como se demonstrará a seguir.

Em primeiro lugar, coloca o elemento geográfico, também chamado de região. Essa parte do todo designado como nação, diz respeito às divisões e fronteiras geográficas propriamente ditas. No mesmo sentido, se o povo se encontra sob o mesmo território e possui as mesmas fronteiras naturais, “[...] além de concentrar e circunscrever e por vezes defender de agressões estrangeiras uma nacionalidade" (MANCINI, 2003, p. 35), esse elemento também proporciona aos habitantes “[...] uma conformidade maior nas condições do desenvolvimento físico e moral e, portanto, maior capacidade de vínculos jurídicos recíprocos. ${ }^{30}$ (MANCINI, 2003, p. 35)

Em resumo,

A natureza do país e a produção do solo, elas somente servem para determinar o gênero de vida e a direção do desenvolvimento nacional. Nascendo nos montes rochosos ou na selvagem liberdade das florestas, um povo é caçador. Surgindo no meio de estéreis e intermináveis planícies, é pastor. Em vales irrigados ou em férteis colinas, abraça a vida agrícola. Nas costas do mar, se torna navegador. (MANCINI, 2003, p. 34)

Mancini manifesta-se no sentido de que "[...] a mente organizadora do universo que quis a humanidade repartida em diversas famílias" (MANCINI, 2003, p. 34), referindo-se à Providência $^{31}$. Aliás, o jurista italiano se refere diversas vezes à vontade divina como comandante da organização das Nações, “[...] destinadas pela natureza e pela Providência a se regerem livres e independentes" (MANCINI, 2003, p. 61).

As fronteiras naturais do território, portanto, constituiriam o primeiro elemento, seguido pelo elemento etnográfico, ou seja, a raça ${ }^{32}$. É de ser relevado que, na visão do autor, “[...] entre os homens há uma evidente pluralidade de raças com caracteres mais ou menos distintos, das quais as mais afastadas são a branca e a negra, sem contudo sair dos limites de variedades naturais, de uma espécie original única." (MANCINI, 2003, p. 35)

\footnotetext{
${ }^{29}$ Mancini difunde sua ideia de que a Ciência é "[...] guia da vida e preparação conscienciosa para uma atividade prática e operativa" e que "deve chegar a conclusões positivas e eficazes para os ulteriores destinos da humanidade.” (MANCINI, 2003, p. 73-74). Por isso não serve para sustentar "estéreis e inúteis conhecimentos especulativos e abstratos".

${ }^{30}$ Acerca da moralidade apontada, importante revelar a que "Mancini afirma o papel originário da pessoa como sujeito de direitos "do bem moral, do bem sensível e do bem social" (NUZZO, 2012, p. 3008). A ética rege os atos da vontade humana nas suas relações com o único bem moral.". Tradução livre de "M. afferma il ruolo originario della persona come soggetto dei diritti "del bene morale, del bene sensibile e del bene sociale". L"etica regge gli atti della volontà umana ne" suoi rapporti col solo bene morale.".
} 
Assim, a raça, seria a expressão de uma identidade sanguínea e de origem, como uma relação que retrata a família. Faz uma relação entre a família e a Nação, asseverando que: “[...] a nação, em sua primitiva gênese história, não pôde ser outra que a própria família, a qual se ampliou por descendência e por gerações sobre o território que ocupava ou uma associação de famílias unidas entre si pela religião dos conúbios.” (MANCINI, 2003, p. 33)

Por fim, destaca-se que a raça “[...] substrato de si próprio, esse conjunto de qualidades físicas e morais que se tem em comum com os próprios irmãos que o homem costuma amar na raça em que nasce." (MANCINI, 2003, p. 36)

Visando justificar a impossibilidade da existência de uma nação com diversidade de raças ratifica que "[...] onde diversas raças conviveram sobre o mesmo solo ou se superpuseram violentamente, não se obteve, nem era possível obter, a constituição de uma nacionalidade, a não ser depois da lenta fusão de umas com as outras, a absorção das qualidades recíprocas e, portanto, a formação de uma raça nova, de características compostas. (MANCINI, 2003, p. 36)

Outro importante elemento constitutivo da nação é o elemento racional, ou seja, a língua. Para Mancini, a língua comum é o maior e mais forte vínculo que uma nação deve ter, já que a língua é "fonte muito abundante de ideias" e revela "[...] o gênio e a condição intelectual de uma nação" (MANCINI, 2003, p. 37)

\footnotetext{
${ }^{31} \mathrm{O}$ autor italiano cita diversas vezes Deus como detentor do poder moral da lei jurídica: O bem moral, que não se limita através do tempo e do espaço deriva de Deus “[...] supremo legislador dos povos". Esse é o poder que ordena a humanidade, nascente da obrigação entre as nações. "[...] ele é, portanto, o universal, o agregador, o cosmopolita, o liame divino ou racional entre os povos." (MANCINI, 2003, p. 53). É certo que essa força varia de acordo com cada povo, sua cultura e seu conhecimento, conforme relembra o autor.

32 Alguns teóricos atribuem as bases de governos totalitários, como o fascismo e o nazismo, e as leis racistas italianas de 1938, à teoria das nacionalidades, ou seja, a doutrina da nacionalidade seria ilusória e perigosa pela sua própria concepção. Mas, como afirma Messineo (2013, p. 890) "[...] Mancini não compara nacionalidade e raça, como as teorias nazistas mais tarde fariam. Uma teoria de nacionalidade poderia existir mesmo sem depender-se das considerações raciais. A concepção de Mancini é formada por múltiplos „fatores de nacionalidade", tais como a história, costumes, leis, religião, território e idioma, sendo a raça apenas um dos fatores. Para Mancini, a consciência da nacionalidade é o elemento essencial quando combinada com os outros fatores, então uma nação é, por fim, o que um determinado grupo de pessoas acredita que é. Porém essa abordagem levemente diversificada não impede que mais tarde o uso ideológico da ideia de „nação" se torne uma ferramenta no arsenal intelectual das detestáveis doutrinas supremacistas". Tradução Livre de "[...] Mancini does not equate nationality and race, as Nazi theories would later do. A theory of nationality could exist even independently of racial considerations. Mancini's conception is shaped by multiple 'factors of nationality', such as history, customs, laws, religion, territory and language, with race being only one of these. For Mancini, a 'consciousness of nationality' is the essential element binding all of these factors together, so that a nation is, ultimately, what an organised people believe it is. But this slightly more nuanced approach did not impede the later ideological use of the idea of 'nation' as a tool in the intellectual arsenal of abhorrent supremacist doctrines." (MESSINEO, 2013, p. 890)
} 
Posto isso, a esses três elementos descritos, se ligam outros como crenças religiosas, costumes, leis e instituições sociais, além da história e das tradições da vida nacional que representam "[...] Um secreto e incessante processo de assimilação" que "[...] desenvolve desse modo um espírito e uma tendência nacional que o tempo fortalece e lhes confere formas mais esculpidas, sendo que em dois povos não são jamais de todo semelhantes." (MANCINI, 2003, p. 37)

Entretanto, não basta a simples reunião desses elementos para a caracterização de um Nação, como será visto adiante.

\title{
4. A consciência da nacionalidade na teoria manciniana e o paradigma estatalista de direito internacional
}

Finalmente alcançamos o principal elemento, que dá vida aos demais: a consciência da nacionalidade.

Somente as condições históricas e naturais não são suficientes para se estabelecer uma Nação, como anuncia Mancini (2003, p. 38):

Esses elementos são como matéria inerte capaz de viver, mas em que não foi inculcado ainda o sopro da vida. Ora, esse espírito vital, essa divina realização do ser de uma nação, esse princípio de sua existência visível (...) é a consciência da nacionalidade, o sentimento que ela adquire de si mesma e que a torna capaz de se constituir internamente e de se manifestar externamente.

Por essa razão a Nação ${ }^{33}$, não seria um conceito material somente, mas também espiritual, fato que foi alvo de críticas que serão exploradas adiante. Acerca desse valor material, vale destacar que

\begin{abstract}
Os sinais materiais que a mão de Deus traçou, não são mais que indicadores, que a base sobre as quais se devem apoiar os verdadeiros elementos capazes de determinar a nação: o território, a raça, a língua, as tradições são simples fatos livres de qualquer incentivo à ação, se não lhe atribuir um valor espiritual, que designe quais elementos de união dos indivíduos da nação da terra, características e exclusivas de cada uma e diante do povo através desses elementos naturais vêm à consciência da diversidade. É exatamente a consciência da nacionalidade o elemento principal, o verdadeiro elemento constitutivo da nação. ${ }^{34}$ (MONACO, 1967, p. 226)
\end{abstract}

\footnotetext{
${ }^{33}$ Mancini (2003, p. 39) conceitua as nacionalidades como sendo aquelas que: “[...] nos dão razão em reconhecer nela uma sociedade natural de homens com unidade de território, de origem, de costumes e de língua, configurados numa vida em comum e numa consciência social."
} 
Como resultado, esse último e importantíssimo elemento, representaria uma “[...] unidade moral de um pensamento comum", “é aquele "penso, logo existo" dos filósofos, aplicado à nacionalidade.” (MANCINI, 2003, p. 38)

Sem esse sentimento adquirido sobre si mesmo, os outros elementos ficam inertes e privados de espírito e de vida. Por conseguinte, a consciência da nacionalidade é aquilo que unifica, que dá força, não havendo nacionalidade anterior ao surgimento desse elemento. Em suma, a consciência comum é um "elemento espiritual animador das nacionalidades." (MANCINI, 2003, p. 38)

\footnotetext{
${ }^{34}$ Tradução livre de "I segni materiali che la mano di Dio ha tracciato, non sono che indicatori, non sono che la base su cui dovranno poggiare i veri elementi capaci di determinare la nazione: il territorio, la razza, la lingua, le tradizioni sono simplice fatti privi di qualsiasi incentivo all"azione, se ad essi non viene attribuito un più altro valore spirituale, che li designi quali elementi di unione degli individui delle nazione della terra, caratteristici ed esclusivi di ognuna e prima che i popoli attraverso questi elementi naturali giungano alla coscienza della propria diversità da tutti gli altri. È proprio la coscienza della nazionalità l"elemento primo, il vero elemento constitutivo della nazione." (MONACO, 1967, p. 226)

35 Inclusive, o jurista italiano equipara liberdade e nacionalidade quando estabelece que: "O direito de nacionalidade, portanto, não é senão a mesma liberdade do indivíduo, estendida ao desenvolvimento comum do agregado orgânico dos indivíduos que formam as nações. A nacionalidade não é senão a explicação coletiva da liberdade e, no entanto, é coisa santa e divina como a própria liberdade.” (MANCINI, 2003, p. 39)

${ }^{36}$ Nesse aspecto, deve-se atentar para um moderno princípio regulador das relações entre os Estados, a autodeterminação dos povos. Extrai-se do ensaio de Biazi (2014, p. 18) que “[...] mesmo não podendo adaptar plenamente o princípio de nacionalidade ao moderno princípio de autodeterminação dos povos, é inegável que as teorias desenvolvidas no seio da escola italiana de direito internacional contribuíram enormemente para o desenvolvimento desse último conceito. A ideia de que os povos têm o direito de determinar por si mesmos os próprios destinos, sem a interferência por parte de outras entidades, pode ser reconhecida nas fórmulas de Mancini "a livre interna constituição de uma nação" e "sua autonomia em face às outras Nações". E, ainda, "[...] Eis aqui delineados aqueles conceitos que são o fundamento do moderno princípio de autodeterminação dos povos (Consagrado no artigo 1, § 2 e no artigo 55 da Carta da ONU, onde se menciona "o princípio da igualdade de direito e dos povos e do seu direito à autodeterminação." Ambas as normas foram utilizadas no passado para promover o processo de descolonização. Alguns autores ilustres afirmam que o princípio de autodeterminação dos povos está no ponto de encontro de dois conceitos: princípio das nacionalidades e a ideia democrática.)" (BIAZI, 2014, p. 47). Para um estudo mais aprofundado sobre o conceito contemporâneo do princípio de autodeterminação dos povos, ver a contribuição de Chiara Antonia Sofia Mafrica Biazi. In: BIAZI, Chiara Antonia Sofia Mafrica. Representações do Princípio de Nacionalidade na Doutrina Internacionalista do século XIX na construção do Princípio de Autodeterminação dos Povos: continuidades e rupturas em um discurso liberal. Florianópolis: Universidade Federal de Santa Catarina, 2014, 234 p. Dissertação (Mestrado) - Programa de Pós- Graduação em Direito, Universidade Federal de Santa Catarina, Florianópolis, 2014.

37 Para uma compreensão mais apurada sobre o nascedouro do federalismo e o debate filosófico-politico federalista que envolveu a organização dos estados norte-americanos, ver o clássico HALMILTON, Alexander; MADISON, James; JAY John. O Federalista. Tradução de Hiltomar Martins Oliveira. Belo Horizonte: Editora Líder, 2003.

38 Tradução livre de "Aspirazioni nazionali e unificazione statale potevano coincidere e condurre all"edificazione di uno stato nazionale, come nel caso italiano, ma alla luce di quando accadeva in Germania e
} 
Então, o conjunto de elementos trazidos por Mancini, quais sejam, a região, a raça, a língua, as crenças, os costumes, etc., somados a tomada de consciência comum faz com que nasça um espírito nacional e uma tendência real de unificação.

Importante frisar que, para o autor, é um dever e um direito dos indivíduos a conservação e o desenvolvimento da nacionalidade, bem como o exercício da liberdade ${ }^{35}$.

Dessa forma, pode-se constatar que dois requisitos devem estar presentes para que uma nação esteja em estado naturalmente perfeito: (1) a livre constituição interna da nação e (2) sua autonomia independente com relação às nações estrangeiras. Assevera ainda que internamente a nação é constituída pela constituição física - que seria a posse de todo território nacional - e pela constituição moral - que se constitui em um governo próprio capaz

de manter e dirigir a nação ${ }^{36}$ Importante, a respeito desse assunto, evidenciar que não importa se a organização interna da Nação ocorra de forma federal ou unitária ${ }^{37}$. Mancini assevera que esse governo próprio não deve significar obrigatoriamente um estado unitário, com concentração de poderes, mas pode se estabelecer internamente

[...] de forma unitária ou federal, contanto que a unidade orgânica seja resultante da constituição de um poder central, ao qual está confiada a tutela dos interesses realmente comuns a todas as partes da nacionalidade e àquela particularmente da defesa do território. Quem poderia negar a existência de uma nacionalidade no território da Alemanha ou naquele dos Estados da União Americana, só porque um vínculo federativo une as partes? O gênio dos povos, as circunstâncias dos lugares e dos tempos podem tornar mais ou menos estreitas estas relações entre as diversas partes vivas da nacionalidade, podem atribuir maior ou menor autoridade àquele centro comum de vida. Mas o direito da nacionalidade está a salvo. O resto é obra do tempo e da liberdade, fecundadores incessantes da espontânea elaboração da vida dos povos. (MANCINI, 2003, p. 41)

Em outras palavras, para ser uma Nação, não é obrigatório que haja absoluta unidade do Estado, pode haver também uma forma federal, com maior autonomia dos entes. Importante relembrar unicamente que a livre constituição interna é um direito sagrado das nacionalidades e, no que se refere a sua autonomia externa, que deriva da livre constituição interna, é a liberdade de se constituir sem coação estrangeira.

Frente a isso, se expressa Mancini: “Um Estado, em que muitas viçosas nacionalidades são sufocadas numa união forçada, não é um corpo político, mas um monstro incapaz de transmitir vida." (MANCINI, 2003, p. 42)

Da mesma forma, pode-se dizer ainda que

Aspirações nacionais e unificação estatal podiam coincidir e conduzir à edificação de um estado nacional, como no caso italiano, mas a luz de quando aconteceu na Alemanha e nos Estados Unidos a existência de nacionalidade não foi colocada em 
discussão os vínculos federativos e a unicidade do sujeito politico que continha. ${ }^{38}$ (NUZZO, 2007, p. 165)

Superada essa especificidade do pensamento manciniano, passa-se a se ater ao paradigma estatalista do Direito Internacional, absolutamente desaprovada pelo jurista.

Nas palavras de Mancini (2003, p. 42): “[...] na gênese dos direitos internacionais a Nação e não o Estado representa a unidade elementar, a mônade racional da ciência.” Logo é a nacionalidade que fundamenta todos os outros direitos entre as nações. Sob esse pensamento, edifica sua tese do direito universal que

[...] inicia a escola italiana de direito internacional e é baseada sobre o princípio que, no lugar do estado histórico, a nacionalidade é o verdadeiro sujeito, ao lado da pessoa humana, do direito universal e, por tanto, do direito público internacional e è titular de todos os direitos absolutos e inalienáveis tradicionalmente atribuídos ao Estado (igualdade, liberdade - por sua vez incluída de independência e soberania moralidade, dignidade e honra, personalidade e „sociabilidade $\left.{ }^{e c}\right)^{39}$ (NUZZO, 2012, p. 311)

Dessa forma, para ganhar um status de ciência tão desejado, para Mancini, o Direito Internacional deveria resguardar um rigor conceitual renunciando esse conceito vago impreciso e perigoso para a ordem politica da Europa daquele tempo.

A doutrina italiana tinha um árduo caminho a seguir e uma questão fundamental a responder: qual era o papel do Estado? Pois ao mesmo tempo em que o Estado deveria ser o protagonista na construção do nascente Direito Internacional, ele também poderia reduzir esse novo saber a uma expressão da vontade estatal.

Por isso Mancini quis enfatizar o reconhecimento necessário da dimensão interestatal do Direito Internacional e demonstrar que Estado e Nação estariam em oposição em toda a história da humanidade ${ }^{40}$.

negli Stati americani l"esistenza di più nazionalità non era messa in discussione dai vincoli federativi e dall"unicità del soggetto politico che le conteneva" (NUZZO, 2007, p. 165)

${ }^{39}$ Tradução livre de "(...) dà avvio alla scuola italiana di diritto Internazionale ed è incentrata sul principio che, in luogo dello Stato storico, la nazionalità è il vero soggetto, al pari della persona umana, del diritto universale $e$, pertanto, del diritto pubblico Internazionale ed è titolare di tutti $i$ diritti assoluti ed inalienabili tradizionalmente attribuiti allo Stato (uguaglianza, libertà - a sua volta compreensiva di indipendenza e sovranità - , moralità, dignità e onore, personatilà e „sociabilità".) (NUZZO, 2012, p. 311)

40 Mancini (2003, p. 44-49) faz um breve relato histórico sobre as batalhas enfrentadas pelo Princípio da Nacionalidade, contra a ideia de Conquista, de Sucessão, de Propriedade, da Indústria, da Monarquia universal, etc., visando reforçar o pensamento anteriormente desvendado: aquele que afirma que a ideia mãe da ciência é a nacionalidade, e não o Estado. 
Acerca do Princípio da Nacionalidade, Mancini (2003, p. 51) elabora um questionário com respostas arrematadas, com o escopo de convencer sobre a centralidade da concepção de Nação:

[...] ele é recomendado também pela admirável simplicidade que pode introduzir na ciência do direito dos povos, a qual, sob a proteção da lei suprema do direitouniversal, viria assim dispor-se e girar totalmente em torno de uma única ideia, causa e limite de todas as outras. De fato, único seria e sempre o mesmo, neste sistema, o sujeito do direito entre os povos, a nacionalidade. Qual seria o objeto e a matéria dele e qual o critério científico geral, senão a aplicação do princípio de nacionalidade? Qual o limite racional do direito de cada nacionalidade? As outras nacionalidades. Qual a garantia ao mesmo tempo justa e praticamente eficaz do direito dos povos? O respeito e a independência de cada nacionalidade. Por último, qual o fim supremo do direito dos povos? A "humanidade das nações" de Vico, isto é, a celebração da humanidade e de seu progresso civil no livre, harmonioso e completo desenvolvimento das nacionalidades."

Alguns poderiam injustamente defender que o Princípio da Nacionalidade é um princípio negativo, que gera egoísmo e isolamento e até mesmo que depende da sorte para ser agraciada por um ente divino. Mas Mancini se volta contra esse argumento e começa a discorrer sobre a coletividade dos povos e a real possibilidade de uma vida comum. Para tanto, pondera sobre um último aspecto da nacionalidade, que "[...] reconhece a si mesma em todas as outras nacionalidades e se sente obrigada a respeitá-las como tantos objetos do direito." (MANCINI, 2003, p. 52), e por isso todas as nacionalidades estão protegidas e invioláveis.

Nessa conjuntura o autor manifesta a desigualdade natural entre povos. Segundo ele, a Providência divina não distribuiu de forma igualitária todos os bens e os meios de satisfação da humanidade. Portanto, as Nações precisam se auxiliar mutuamente “[...] não só pela autoridade da razão, mas também pela força compelente da necessidade a se reconhecerem como partes de uma só unidade orgânica, que é o gênero humano.” (MANCINI, 2003, p. 52). Também, a “[...] variedade de suas próprias e distintas personalidades coletivas se coordena no fundo de quadro único e se anima por um espírito vital comum.” (MANCINI, 2003, p. 52)

A leitura da segunda preleção, proferida em Turim em 1852, intitulada "Do Velho e do Novo Direito dos Povos" reafirma a artificialidade do Estado e a impossibilidade de ser considerado o sujeito do Direito Internacional. Consoante ensinamento de Dal Ri (2014, p. 264), “[...] em Mancini, a "Nação”, entidade natural e necessária, finalmente encontrava a libertação após o longo e exaustivo percurso através dos séculos, aprisionada por uma ficção jurídica, artificial e arbitraria, devendo, então, dela se desvincular totalmente.” 
O principal argumento utilizado pelo discurso manciniano é que a Nação gera de forma espontânea uma infinidade de relações jurídicas, sendo suficientemente forte e resiste às variações e transformações do Estado. Em verdade, no dizer de Hespanha (2005, p. 384)

\begin{abstract}
O Estado, tal como surgira dos movimentos políticos contratualistas, era, de fato, uma abstração. Produto de um contrato idealizado, realizado entre sujeitos meramente racionais, cujo conteúdo decorria das regras de uma Razão a-histórica. O Estado (e o código) não têm nem lugar, nem tempo. São formas universais, indiferentes a quaisquer particularidades culturais ou nacionais. Era isto que uma cultura de raízes nacionalistas, ancorada nas especificidades culturais dos povos, não podia aceitar. Uma organização política e jurídica indiferenciada, exportável, universalizante, aparecia quando confrontada com os particularismos das tradições nacionais, como um artificialismo a rejeitar.
\end{abstract}

Como efeito, do apanhado histórico feito na conferência supracitada, Mancini (2003, p. 120) ressalta com pesar que o Direito Internacional foi a parte do Direito que menos teve progressos no último século, uma vez que projetou erroneamente no Estado a construção de uma ciência:

O Direito internacional público em sua expressão positiva repousa ainda substancialmente sobre a antiga base feudal, considerando os Estados como patrimônio de algumas famílias e poder-se-ia dizer que continua sendo o Direito dos governos, antes que aquele das nações.

Em remante, segundo a teoria manciniana, os Estados são artificiais e arbitrários e as Nações são naturais e necessárias. Porquanto isso justifica a alteração do sujeito de Direito Internacional do primeiro para a segunda: a Nação.

Apesar de todo o seu esforço em delinear as peculiaridades do Princípio das Nacionalidades, os críticos negavam a aplicabilidade de seu princípio no âmbito jurídico, como será demonstrado no item seguinte.

\title{
5. A abstração dos elementos substanciais da nacionalidade: críticas à teoria
}

Dal Ri Junior expõe que a proposta do jurista italiano deixou algumas lacunas e foi alvo de críticas dos estudiosos da época, cuja mais reiterada é aquela acerca da dificuldade em expor o que seria na prática uma "Nação", “[...] não mais enquanto entidade antropológica, mas sim enquanto sujeito de Direito Internacional.” (DAL RI, 2014, p. 265)

De outro lado, não se pode negar que o pensamento de Mancini é de extrema importância, ainda atualmente, para que seja possível refletir e redefinir o papel do Estado como sujeito. 
As observações de Mancini se consubstanciam em "[...] uma proposta teórica que se torna funcional à construção de um mito necessário para, no imaginário coletivo e político, não só unificar, mas consolidar o novo Estado italiano.” (DAL RI, 2014, p. 266) e irromper um sentimento nacional.

Aponta, ainda que a teoria da Nação foi avaliada por vários internacionalistas que podem ser separados em dois grupos: “[...] um primeiro que, mesmo legitimando o princípio das nacionalidade como fundamento da consciência nacional, não o considerava fundamento do direito internacional, e um segundo grupo, que não reconhecia em nenhum dos seus aspectos o princípio das nacionalidades.” (DAL RI, 2014, p. 268)

Pascuale Fiore fez severas criticas à teoria das nacionalidades de Mancini. Ele não julgava que a questão da raça e da língua por si só formassem um vínculo essencial para se formar uma Nação. Assim como a religião, os costumes e etc., seriam todos elementos exteriores e secundários, em relação à consciência espontânea das sociedades. Para Fiore “a Nação seria [...] uma livre e espontânea agregação de homens" e que somente poderia subsistir [...] supondo o princípio da espontaneidade e da liberdade” (DAL RI, 2014, p. 271)

Assim, baseado em elementos volitivos, Fiore admite que a religião, raça, hábitos, território são importantíssimos elementos que dão identidade e homogeneízam os indivíduos, mas reforça que não são os elementos substanciais a caracterizarem uma Nação.

Mas, o principal alvo de críticas e discordâncias foi, sem dúvida, a pedra angular do discurso manciniano: a consciência da nacionalidade. Monaco (1967, p. 233) amplia a discussão afirmando que

\begin{abstract}
A nacionalidade, de fato é uma teoria que Mancini não demonstrou, mas descreveu e aceitou como um dado, um fato evidente que salta aos olhos e do qual ele não tenta nem mesmo uma demonstração: Mancini a investiga nos seus fatores essenciais, que mostra a força reguladora da história desde os tempos mais antigos - tempos em que, por outro lado, não se pode falar ainda de nacionalidade, mas apenas, se alguma coisa, de Estado, como irá dizer após o próprio Mancini, mas não dá uma verdadeira demonstração e, então, uma definição jurídica, o que deveria ter feito antes de colocar a nacionalidade como princípio basilar do direito das gentes. ${ }^{41}$
\end{abstract}

No mesmo sentido, alguns contestam a possibilidade dos conceitos de nação e nacionalidade ser investigados no plano jurídico, pois seriam um princípio ou um sentimento sem caráter forense. Em relação ao exposto, declara Monaco (1967, p. 233) que Mancini se equivocou ao "[...] ter cristalizado o conceito de nacionalidade, princípio essencialmente ético, em uma noção jurídica, ao contrário na noção principal do direito, no seu princípio-base sem perceber que a nação para tornar-se um valor jurídico deve se apresentar como Estado.”42 
O pensamento manciniano sofreu severas críticas na Itália e também no exterior. Os críticos contestavam, sobretudo "[...] a centralidade reconhecida à consciência da nacionalidade, criticavam a ambiguidade e viam nessa o canal pelo qual elementos morais ou psicológicos tinham encontrado espaço dentro do discurso politico-jurídico". ${ }^{43}$ (NUZZO, 2012, p. 97)

Em consonância com essa avaliação, os críticos asseguram que Mancini elevou sua teoria a algo simbólico e contemplativo, o que poderia representar, inclusive, um perigo de transformar o princípio de nacionalidade em um princípio de ordem religiosa.

Contudo, a estruturação de uma ciência jurídica internacionalista "[...] impunha ao contrário, distinguir o plano jurídico do plano moral. [...] E, também, “[...] exigia o cancelamento de cada traço do antigo direito das gentes e a sua transformação em direito positivo." ${ }^{44}$ (NUZZO, 2012, p. 97)

O próprio Mancini (2003, p. 60) nos apresenta os opositores da sua teoria sobre a nacionalidade. Os denomina de (1) utopistas humanitários e (2) diplomatas da força. O primeiro grupo nega a possibilidade de “(...) fundir mais intimamente possível todas as populações que habitam o globo, de estabelecer uma doutrina de comunhão e solidariedade universal"; o segundo grupo, cujos membros visam poder e riqueza, só conseguem enxergar os acordos diplomáticos como autoridade principal. O jurista italiano, ainda, frisa

\footnotetext{
41 Tradução livre de "La nazionalitá, infatti è una teoria che il Mancini non ha dimostrato, ma descritto ed accettato come um dato, un fato evidente, che balza subito agli occhi, e di cui egli non tenta neppure una dimostrazione: Mancini la indaga nei suoi fattori essenziale, la mostra quale forza regolatrice della storia fin dai tempi più antichi - tempi in cui, per altro, non può parlarsi ancora di nazionalità, ma solo, semmai, di Stati, come dirá in seguito per altro lo stesso Mancini, ma non ne dà una vera e propria dimostrazione e, quindi, una definizione giuridica, cosa che avrebbe dovuto fare prima di porre la nazionalità principio-base del diritto dele genti." (MONACO, 1967, p. 233)

${ }_{42}$ Tradução livre de “(...) aver cristalizzato il concetto di nazionalità principio essenzialmente etico, in una nozione giuridica, anzi nella nozione principale dell diritto, nel suo principio-base senza rendersi conto che la nazione per divenire un valore giuridico, deve presentare come Stato. ” (MONACO, 1967, p. 233)

43 Tradução livre de "la centralità riconosciuta alla coscienza della nazionalità, ne criticavano l"ambiguità $e$ vedevano in essa il canale attraverso il quale elementi morali o psicologici avevano trovato spazio all"interno della discorsività politico-giuridica." (NUZZO, 2012, p. 97)

${ }^{44}$ Tradução livre de “(...) imponeva invece, di distinguere il piano giuridico dal piano morale. (...) richiedeva la cancellazione d"ogni traccia del vecchio diritto delle genti e la sua trasformazione in diritto positivo." (NUZZO, 2012, p. 97)
} 
[...] nosso princípio aparece para os primeiros por demais mesquinho e estreito. Para os segundos, demasiado amplo e distante do mundo dos fatos. Para aqueles, ainda demasiado dominado por interesses exclusivos e subjugado pelas tradições do passado; para estes, demasiado fácil para condenar e violar as realidades existentes, graças a uma abstrata generalidade. Alguns o acham tímido, outros, revolucionário; para alguns é pouco, para outros, é demais.” (MANCINI, 2003, p. 66)

No discurso manciniano o segundo grupo deve ser considerado inimigo, pois visa criar uma união das raças com destruição das nacionalidades. Já o primeiro grupo deve ser encarado como virtuoso. Esclarece que "professamos também nós as doutrinas da paz, da unidade da espécie, da fraternidade dos povos. Para nós também o bem e a perfectibilidade indefinida do gênero humano, soma e resultado de cada indivíduo e de todas as associações humanas, é o último objetivo prático dos esforços da civilização.” (MANCINI, 2003, p. 67)

Posto isso, não há que se negar que Mancini teve destaque no Direito Internacional principalmente por ter transplantado os conceitos de nação e nacionalidade da história, da filosofia e da política para a ciência jurídica, ou seja, "sua contribuição seria marcada por uma suposta originalidade ao traduzir os conceitos e noções advindos dos universos literário e político, para uma nascente ciência do Direito Internacional” (DAL RI, 2014, p. 279)

Apesar de transparecer um nacionalismo exacerbado, principalmente quando trata do elemento raça, não era seu objetivo criar desavenças entre os povos, menos ainda separá-los. Isso fica claro em diversas passagens de sua obra, como por exemplo, quando afirma que a paz é “(...) o estado natural, legítimo e perpétuo entre os povos. Melhor, o espírito de fraternidade induz entre as nações uma nobre competição de benefícios recíprocos e de ajuda para ampliar o aperfeiçoamento progressivo da humanidade." (MANCINI, 2003, p. 64)

Nessa esteira podemos concluir que devemos enxergar a teoria manciniana como fruto de seu tempo. Não se pode perder de vista a necessidade de ver o jurista como um homem do século XIX, afinal suas concepções refletem-no como homem de seu tempo, mergulhado nas peculiaridade do objetivo que tinha em mente: a unificação da península italiana.

\section{CONSIDERAÇÕES FINAIS}

A Itália do séc. XIX foi um terreno fértil para a construção do pensamento manciniano. Conforme explorado nesse estudo, Mancini foi um homem de seu tempo e seu contexto histórico foi decisivo para o desenvolvimento de uma nova ciência do Direito Internacional. 
A Nação, considerada pelo jurista italiano como o grande personagem que define o Direito Internacional, é um ente natural que faz parte da unidade orgânica do gênero humano. Dentro desse contexto, foram explorados a fundo os elementos que constituem esse conceito, quais sejam, o geográfico, o etnográfico, o racional, as crenças religiosas, os costumes, além das tradições da vida nacional.

Viu-se que o Direito Internacional era uma espécie do gênero Direito Humano Universal, o direito das gentes, visto como uma lei natural de coexistência, como uma ampla ordem de relações jurídicas, de homogeneidade que se fundamenta no princípio das nacionalidades.

Ficou evidente que, para Mancini, o único sujeito de Direito Internacional seria a nação, amplamente considerada enquanto entidade natural com unidade de território, origem, costumes e de língua, sendo a consciência social que a tornaria capaz de se constituir internamente e de se manifestar externamente.

Mancini afirma que o conjunto dos elementos elencados compõe a natureza única de cada povo e faz nascer uma coletividade de relações materiais e espirituais que capaz de formar uma aliança entre os indivíduos.

De forma envolvente, Mancini nos apresenta à dissolução do velho Direito Internacional e à empreendida reconstrução de um direito renovado e melhor.

Além disso, as discussões articuladas ao redor da subjetividade no mundo do direito, ou seja, da definiçãa do sujeito do Direito Internacional - Estado ou a Nação - foram intensas e férteis e propiciaram, sem dúvida, um aprimoramento do estudo dessa ciência.

Enfim, os traços mais importantes, dentro do discurso manciniano, foram estes: (a) a relação de Estado e Nação; (b) a individualidade das Nações; (c) o limite ao justo desenvolvimento das nações e a livre coexistência de todas.

A partir de então, debruçou-se sobre a afirmação de que a história aponta um progresso continuo da humanidade indicando a progressiva união das nacionalidades, com o intuito de demonstrar a necessidade da quebra de antigos paradigmas que colocavam o Estado como centro do Direito Internacional. Como se viu, Mancini assevera que os Estados são entes artificiais e arbitrários e devem ser substituídos pelo conceito de Nações, entes naturais e necessários.

Portanto, a teoria da nacionalidade é uma classificação racional que está inserida no princípio geral do direito universal. Isso porque Mancini identificava nação como uma 
sociedade natural que continha certos elementos constitutivos formadores da natureza dos povos, como já frisado em linhas pretéritas.

Mancini exerceu uma brilhante atividade de jurista e foi precursor de uma grande mudança de paradigmas na ciência do Direito Internacional, marcando de forma definitiva a história dessa área do conhecimento jurídico.

Enfim, pode-se concluir que o evidente destaque atribuído a Mancini se deve principalmente ao fato de ter transplantado os conceitos de nação e nacionalidade da história, da filosofia e da política para a ciência jurídica. Em outras palavras, sua contribuição foi marcada pela originalidade e ousadia de traduzir os conceitos de outras áreas do conhecimento para uma nascente ciência do Direito Internacional.

\section{REFERÊNCIAS BIBLIOGRÁFICAS}

BIAZI, Chiara Antonia Sofia Mafrica. Representações do Princípio de Nacionalidade na Doutrina Internacionalista do século XIX na construção do Princípio de Autodeterminação dos Povos: continuidades e rupturas em um discurso liberal. Florianópolis: Universidade Federal de Santa Catarina, 2014, 234 p. Dissertação (Mestrado) Programa de Pós- Graduação em Direito, Universidade Federal de Santa Catarina, Florianópolis, 2014.

DAL RI JÚNIOR, Arno. Pasquale Stanislao Mancini. In: DAL RI JÚNIOR, Arno; VELOSO, Paulo Potiara de Alcântara; LIMA Lucas Carlos (org.). A Formação da Ciência do Direito Internacional. 1 ed. Ijuí: Unijuí, p. 253-284, 2014.

GROTIUS, Hugo. O direito da guerra e da paz. Tradução de Ciro Mioranza. Ijuí: Editora Unijuí, 2004.

HESPANHA, Antônio Manuel. Cultura jurídica europeia: síntese de um milênio. Florianópolis: Fundação Boiteux, 2005

MACEDO, Paulo Emílio Vauthier Borges. Hugo Grócio e o Direito: O Jurista da Guerra e da Paz. Rio de Janeiro: Editora Lumen Juris, 2006.

MANCINI, Pasquale Stanislao. A vida dos povos na humanidade. In: Direito internacional (Diritto internazionale. Prelezioni). Tradução de Ciro Mioranza. Ijuí: Unijuí, 2003.

MANCINI, Pasquale Stanislao. Direito internacional. (Diritto Internazionale. Prelezioni). Ijuí: Unijuí, 2003.

MESSINEO, Francesco. Is there na italian conception of International Law?. Cambridge Journal of International and Comparative Law. Issue 4, Vol. 2, p. 879-905, 2013. 
MONACO, Maria Assunta. L'idea di nazione in Giuseppe Mancini e in Pasquale Stanislao Mancini. In: Rassegna storica del Risorgimento, vol. 54, fasc. 2, p. 216-236, 1967.

NUZZO, Luigi. Da Mazzini a Mancini: il principio di nazionalità tra politica e diritto. In Giornale di storia costituzionale, n.14, II semestre, 2007.

NUZZO, Luigi. Origini di una scienza: diritto internazionale e colonialismo nel XIX secolo. Frankfurt am Main: Vittorio Klostermann, 2012.

NUZZO, Luigi. Pasquale Stanislao Mancini, ad vocem, Enciclopedia Treccani, Il contributo italiano alla storia del pensiero. Roma: Istituto dell 'eenciclopedia italiana, p. 307-310, 2012. SERENI, Angelo Piero. The Italian conception of international Law. New York: Columbia University Press, 1943, p. 155-156)

TREGGIARI, Ferdinando. Diritto nazionale e diritto della nazionalità. In: Raccolta di scritti in memória di Agostino Curti Galdino. Annali della facoltà di Giurisprudenza, Università degli Studi di Perugia. Napoli: Edizioni scientifiche italiane, n.10, vol. 1, 1991.

VILLEY, Michel. A formação do pensamento jurídico moderno. São Paulo: M. Fontes, 2009. 